Revista IBERC

v. 4, n. 1, p. 168-189, jan./abr. 2021

www.responsabilidadecivil.org/revista-iberc

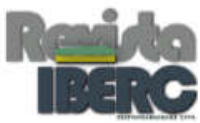

\title{
APRESENTAÇÃO DA OBRA “DA ESTRUTURA À FUNÇÃO DA RESPONSABILIDADE CIVIL: UMA HOMENAGEM DO INSTITUTO BRASILEIRO DE ESTUDOS DE RESPONSABILIDADE CIVIL (IBERC) AO PROFESSOR RENAN LOTUFO"
}

ORGANIZADORA: Fernanda Ivo Pires.
COORDENADORES: Alexandre Guerra; Antônio Carlos Morato; Fernando Rodrigues Martins e Nelson Rosenvald.

ANO: 2021.

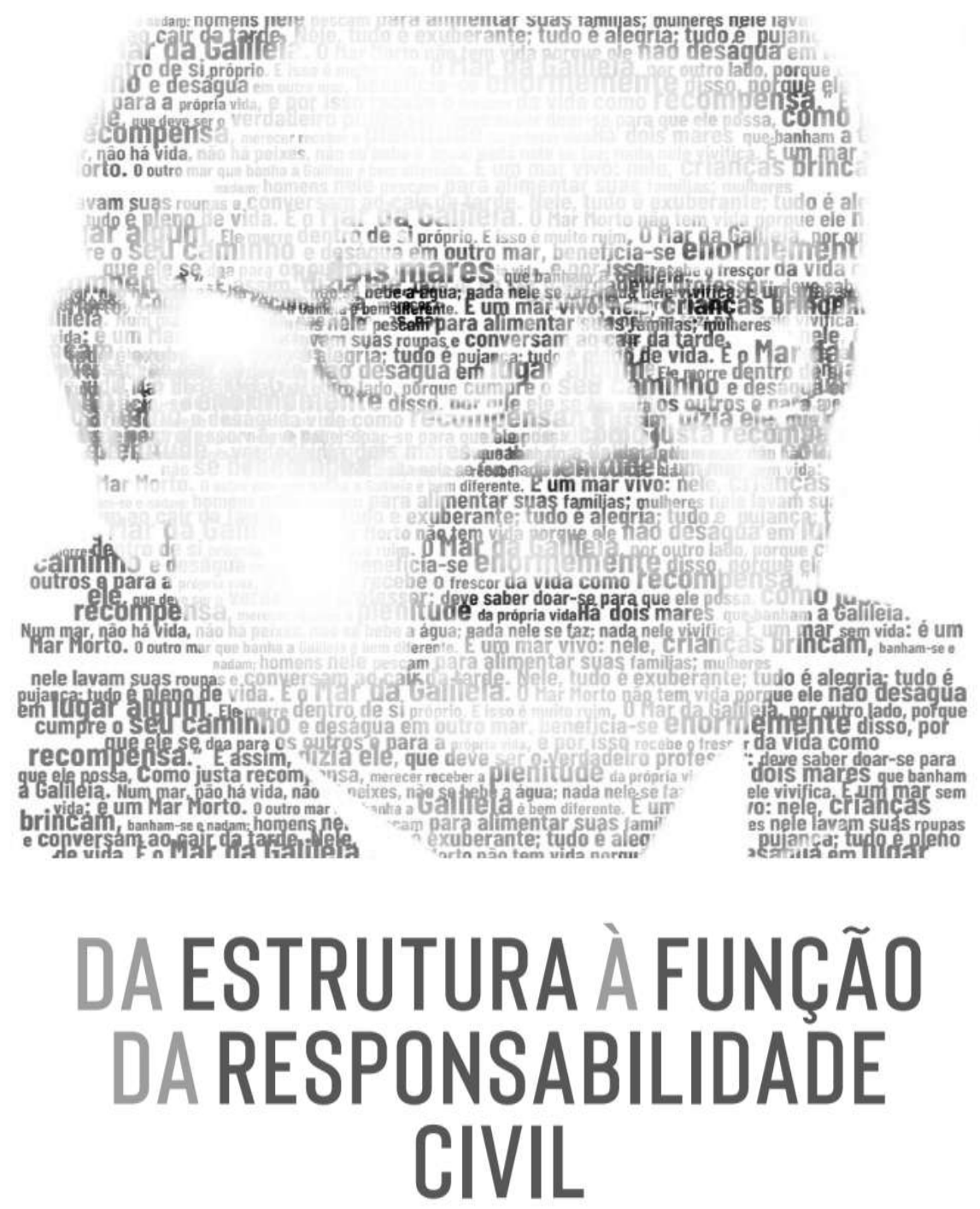

UMA HOMENAGEM DO INSTITUTO BRASILEIRO DE ESTUDOS DE RESPONSABILIDADE CIVIL (IBERC) AO PROFESSOR RENAN LOTUFO 


\section{APRESENTAÇÃO}

No dia 14 de novembro de 2019, no grupo virtual do Instituto Brasileiro de Estudos de Responsabilidade Civil (IBERC), entre diversas mensagens, recordamos um memorável evento com o Professor Renan Lotufo organizado pelo Instituto de Direito Privado (IDP) e pelo Instituto dos Advogados de São Paulo (IASP) e o privilégio de acompanhá-lo naquela oportunidade.

Ao relembrar tal evento, mensagens e mais mensagens foram enviadas ressaltando a importância do professor na carreira acadêmica de tantos integrantes do grupo e, na ocasião, os coordenadores desta obra tomaram a decisão de organizá-la utilizando como base o seu curso de Responsabilidade Civil ministrado na pós-graduação da Faculdade de Direito da Pontifícia Universidade Católica de São Paulo (PUC-SP).

Infelizmente, ainda que tenha sido possível avisar o professor sobre a intenção de organizar tal homenagem por meio de seu filho João Luís Zaratin Lotufo, advogado e professor que elaborou o prefácio desta obra, não foi possível organizá-la antes de seu falecimento em 15 de junho de 2020.

Esta obra conta com autores consagrados e reconhecidos no Brasil e no exterior que mantinham laços de amizade com o Professor Renan Lotufo há décadas, sendo que muitos desses autores foram seus alunos ou assistentes, por ele foram orientados e vieram de todas as regiões do Brasil para cursar o mestrado ou o doutorado na Faculdade de Direito da Pontifícia Universidade Católica de São Paulo (PUC-SP).

Ressalte-se que esta obra inclui autores ainda jovens e que foram orientados pelo professor, da mesma forma que as referências bibliográficas nas disciplinas que ministrava incluíam obras clássicas - nacionais e estrangeiras - ao lado de outras publicadas recentemente por autores promissores que versavam sobre temas até então inéditos ou pouco explorados.

Assim, passamos à apresentação dos textos elaborados para homenagear quem nos ensinou, orientou e continuará vivo por meio dos valiosos ensinamentos eternizados em suas obras.

Emartigointitulado "Responsabilidade civil-evolução histórica", Francisco Amaral aborda a origem e evolução histórica da responsabilidade civil, considerando ser de especial importância a relação entre história e direito civil para a compreensão da experiência jurídica brasileira, principalmente no campo do direito privado. Oautor parte da premissa de que os códigos civis exprimem a cultura jurídica de seu tempo e das sociedades a que se destinam, sendo, simultaneamente, um ponto de chegada, no sentido de representarem o último estágio do processo evolutivo do direito privado, e um ponto de partida para a renovação desse direito em face das novas exigências que a sociedade em processo de mudança exige. Quanto ao conceito de "responsabilidade civil", tanto exprime a obrigação que alguém tem de indenizar outrem, quanto o próprio instituto jurídico formado pelos princípios e normas que disciplinam o nascimento, conteúdo e cumprimento dessa obrigação. Sendo o direito civil um direito de formação histórica e jurisprudencial, é na 
sua historicidade que se encontram os elementos que permitem compreender como a responsabilidade civil evoluiu e se configura hoje em face dos novos desafios da sociedade contemporânea, marcada pelo risco decorrente de uma atividade econômica lucrativa, surgindo a concepção de que o dano deve ser indenizado, independentemente da culpa de agente, mas proveniente do risco derivado da sua atividade econômica produtiva.

Fernanda Ivo Pires brinda o leitor com o instigante tema "Existe uma teoria geral da responsabilidade civil?". Na premissa de que "considerar algo como teoria geral, anseia a demonstração de uma generalidade que possa, ao mesmo tempo, ter esta característicae dar unidade à matéria", a autora principia pela investigação da ilicitude. Na sequência aborda o dano como elemento fundante da responsabilidade civil e posteriormente identifica a unidade de causas quanto às responsabilidades negocial e extranegocial, bem como no tocante às suas consequências. Finaliza, alertando quanto ao fato de que a compreensão de uma Teoria Geral da Responsabilidade Civil não significa encontrar solução uníssona, seja como caminho para qualquer tipo de dano, igualmente para as situações de subjetividade ou de imputação objetiva, ou, ainda, para a responsabilização negocial e extranegocial. Adverte ainda que unificar o dano como pressuposto elementar da Responsabilidade Civil, não restringe o seu escopo à mera reparabilidade de danos. Existem diversas maneiras de responsabilização que perpassam, inclusive, por funções preventivas e precaucionais.

"Danos qualificados constitucionalmente e a formação da norma de proteção de direitos fundamentais no âmbito da responsabilidade civil" é o título do artigo de autoria conjunta de Fernando Rodrigues Martins e Cláudia Lima Marques. Os autores assumem como ponto de partida a ideia da responsabilidade civil, enquanto disciplina analítica, com escopo primordial na concreção das normas de proteção dos direitos fundamentais. Daí a importância do diálogo entre direito constitucional e direito privado, dado que a incompletude sistêmica, encontra na unidade imprescindível conexão entre disposições legais e outras fontes e na ordenação a racionalização e finalidades do Direito. O ilícito constitucional é conceituado como uma violação a deveres fundamentais e os danos qualificados constitucionalmente estão distribuídos tanto na fundamentabilidade individual quanto transindividual, a considerar os bens jusfundamentais em promoção. A violação a direitos fundamentais de outrem ou o atentado aos deveres fundamentais, quer por outro particular ou pelo Estado, são o bastante para o manejo de pleitos de responsabilidade civil, independentemente de estar albergada na Constituição forma correspondente à imputação por danos. Acresça-se ainda a importância da função preventiva da responsabilidade civil, tanto para os direitos de incidência coletiva (bens jusfundamentais), como incidência individual (especialmente aos vulneráveis, textualmente para crianças e pessoas com deficiência),

Silmara Juny de Abreu Chinellato enfrenta o tema "Tutela civil do nascituro: O dano pré-natal". Primeiramente, a autora se alinha com a corrente concepcionista, afastando a da personalidade condicional, sustentando que que a personalidade começa da concepção e não do nascimento com vida, considerando que muitos dos direitos e status do nascituro não dependem do nascimento com vida, como os Direitos da Personalidade. No âmbito dos direitos da quarta geração, aborda o dano pré-natal, tema que não é muito tratado na Doutrina, mas alvo de inúmeros acórdãos. O dano causado a embrião pré-implantatório também é objeto de análise as várias facetas do dano causado ao nascituro implantado, 
seja com relação ao direito à vida, a morte dos pais, o direito à integridade física, direito à honra e direito à integridade psíquica

Em uma atualíssima incursão nas fronteiras entre a responsabilidade civil e o biodireito, Debora Gozzo e Juliano Ralo discorrem sobre o "Melhoramento do embrião e responsabilidade civil do profissional da saúde". Não se discute tão somente a questão do melhoramento do embrião, mas também a responsabilidade do profissional da saúde, uma vez que a mudança no DNA humano pode acarretar toda uma alteração na espécie humana, cujos resultados ainda são desconhecidos, daí a fundamentalidade do princípio da precaução. Tratando-se de profissional liberal, examina-se a sua responsabilidade contratual e de meio, subsistindo o dever de indenizar pelos danos causados a título de culpa lato sensu ou dolo. Em acréscimo, abre-se espaço para a discussão da responsabilidade civil por riscos desconhecidos - liability for unknow risks - aplicando-se a imputação objetiva. Há, ainda, a opção de se determinar a inversão do ônus da prova, sempre que o princípio da precaução, inerente ao uso dessa técnica, for desrespeitado. Concluem os autores que o progresso da ciência nessa área deve obedecer ao princípio da precaução e respeitar a relação de custo/benefício do uso dessas técnicas, de forma a promover o progresso da ciência, sem comprometer o paciente, o meio ambiente e as futuras gerações.

Na sequência, Nestor Duarte examina a questão da "Responsabilidade civil pelo rompimento injustificado das tratativas pré-contratuais". O autor denomina como "angustas" as possibilidades de indenização por rompimento imotivado de negociações, tendo o Juiz de apurar, durante a instrução, se há uma expectativa de concretização do contrato, conscientemente infundida pela parte que vier a romper. Essa exigência se baseia na regra fundamental de que a responsabilidade civil reclama o vínculo direto da conduta do agente com o dano experimentado. Nestor Duarte, inclina-se pela natureza extracontratual da responsabilidade civil pela violação das tratativas, como ofensa legal a um dever preexistente. Apesar de circunstancial a distinção, ela repercute no tocante ao prazo prescricional, cuja orientação modificou-se aplicando-se a prescrição trienal, ressalvando-se o prazo quinquenal contra a Fazenda Pública.

"Responsabilidade pela ruptura das negociações" foi o tema eleito por Francisco Eduardo Loureiro e Hamid Bdine. Os autores abordam alguns dos efeitos da boa-fé na fase que antecede a celebração definitiva dos contratos, quando os contratantes se encaminham para ela, mas ainda não se vincularam por um negócio gerador de efeitos próprios e definidos. Nesta fase do caminho estabelecido até o aperfeiçoamento do contrato, surge, especialmente, a discussão sobre as consequências da ruptura dessas tratativas, considerando-se que, embora autorizados pela autonomia privada a não celebrar o contrato a que originalmente visavam, não se pode deixar de indenizar o outro possível contratante, se nele despertou confiança que posteriormente frustrou. A partir de então, investiga-se a licitude da ruptura e seus limites, bem como sua natureza jurídica, contratual ou extracontratual, e, especialmente, a extensão da indenização devida, quando cabível.

Carlyle Popp nos brinda com o artigo "A responsabilidade pré-negocial diante do negócio inválido: as hipóteses de erro, dolo e coação". Inicialmente, o autor situa a responsabilidade pré-negocial sempre que tendo as partes livremente entrado em tratativas negociais, confiando, pelo menos uma delas (a prejudicada), em suaseriedade, tenha havido violação à boa-fé objetiva e aos deveres laterais da obrigação, gerando dano à parte, seja de natureza moral ou patrimonial, com relação de causa e efeito entre o ato ilícito praticado 
e o prejuízo ocorrido. O contributo decisivo consiste na demonstração de que o instituto da responsabilidade pré-contratual nãose limita às comezinhas hipóteses de rompimento de tratativas, porém, traduz-se em especial relevo para melhor elucidar questões atinentes aos efeitos da invalidade em caso de vícios de consentimento e do comportamento das partes passível de pleito indenizatório, nas hipóteses de erro, dolo e coação. A proteção constituída pelo sistema jurídico no âmbito da formação do contrato, merece ser melhor iluminada por deveres outros, próprios da boa-fé objetiva e da função social do contrato.

Segue o artigo de autor de Rafael Marinangelo, intitulado "A inexecução das obrigações e suas consequências". O autor faz um recorte sobre o vasto tema, mirando nos contratos de construção, nos quais o pagamento tempestivo e de acordo com as premissas legais vigentes é indispensávelà manutenção das condições efetivas da proposta e à saúde financeira da construtora. Para cobrir esse propósito, trata do pagamento de medições de obras de infraestrutura, cujo estudo colhe as mais variadas interpretações em relação ao tema do início da mora, da natureza de sua constituição e do momento de aplicação das consequências previstas no art. 395, do Código Civil. Asprincipais discussões concernem ao adimplemento da prestação da construtora, a cláusula de pagamento a partir da emissão da fatura, a correção monetária e os juros moratórios.

A temática escolhida por Cassio Scarpinella Bueno concerne à "Inexecução das obrigações e suas consequências: diálogo entre o plano processual e o material em homenagem ao Professor Renan Lotufo". O artigo principia com uma justificativa: por mais que os processualistas se dediquem às técnicas inerentes ao direito processual civilé fundamental que não percam de vista que nenhuma delas faz sentido por si só, sem levar em conta a razão de ser do direito processual civil, qual seja, permitir que um determinado conflito de interesses intersubjetivo seja resolvido e concretizado com ânimo de definitividade, ainda que mediante a adoção de um método não jurisdicional. A partir daí o autor faz um aceno às obrigações de fazer e não fazer para, em seguida, focar na tutela jurisdicional concernente a prestações de fazer, de não fazer e de entregar coisa e ao cumprimento das ações relativas às prestações de fazer e de não fazer. Evidencia-se do texto que, por mais avançado que seja o sistema processual civil em vigor, com vistas à concretização da tutela jurisdicional, é absolutamente indispensável que os contornos do direito obrigacional sejam respeitados, tanto quanto a vontade do credor.

"Modelos jurídicos de responsabilidade civil contratual" foio título do ensaio redigido por Paulo Sérgio Velten Pereira. Tendo como premissa teórica a concepção culturalista de Miguel Reale sobre os modelos como estruturas normativas dinâmicas que integram fatos e valores em normas jurídicas que vinculam e obrigam seus destinatários, o autor edifica modelos jurídicos de responsabilidade civil contratual em conexão com os princípios e valores do direito das obrigações. Assim, parte da opção preferencial cumprimento da obrigação em cumprimento ao programa do adimplemento para o inadimplemento relevante, visitando o adimplemento imperfeito, a violação positiva do contrato, a violação eficiente do contrato, a impossibilidade do dano moral no inadimplemento contratual, alcançando a impossibilidade temporária superveniente, modelo jurídico que deve ser desenvolvido no Brasil, a partir das distintas funções da cláusula geral da boa-fé objetiva, com o resgate da autoresponsabilidade das partes contratantes.

O trabalho de Patricia Rizzo Tome se centrou na "Responsabilidade civil, boa-fé e deveres contratuais laterais". Inspirada nas aulas e apostilas do Professor Renan Lotufo, a 
autora se propôs a oferecer um conhecimento mais aprofundado em relação aosinstitutos da responsabilidade civil, boa-fé e deveres contratuais laterais, fazendouma ligação inevitável entre todos os institutos, com intuito de demonstrar a necessidade de aplicação da boa-fé como forma de se alcançar a tão almejada segurança jurídica nas relações obrigacionais, mas principalmente para demonstrar que em sua violação ou dos deveres anexos, as partes estarão sujeitas a reparação dos danos decorrentes, haja vista a incidência do instituto da responsabilidade civil.

Karina Nunes Fritz discorre sobre "A culpa in contrahendo como terceira via de responsabilidade civil". A autora parte do precedente de 2014 do STJ quanto à aplicação do regime contratual a caso de rompimento imotivado das negociações, como divisor de águas no direito brasileiro em relação à controvertida discussão acerca da natureza jurídica da responsabilidade pré-contratual. A discussão em torno do terceiro gênero da responsabilidade civil envolve o repensar e o revisitar de alguns dogmas. A responsabilidade contratual não mais pressupõe a existência do contrato, exigindo, a rigor, apenas a violação de um dever obrigacional, que tanto pode ser um dever de prestação, quanto um dever obrigacional sui generis da boa-fé. Considerando só existir dois regimes legais de responsabilidade civil, explica que a solução dogmaticamente mais adequada parece ser a aplicação cautelosa do regime contratual a todos os casos de responsabilidade por violação dos deveres de consideração, ao invés de atribuir ao aplicador o poder de construir judicialmente um terceiro sistema de responsabilidade civil, o que se refuta devido aos problemas de legitimidade constitucionale segurança jurídica que essa solução provocaria. A incidência do regime contratual aos casos de responsabilidade pré-contratual permite principalmente a aplicação das regras de presunção de culpa, prazo prescricional e início da contagem dos juros de mora.

Silvio Luís Ferreira da Rocha desenvolve o tema "Interesse Contratual Negativo". De início, apresenta reflexões sobre o que é o interesse no estudo da responsabilidade civil contratual, para, na sequência, qualificar o interesse contratual positivo e negativo. Traçando os contornos do instituto com fundamento na doutrina nacional, enfrenta com propriedade a árdua temática da responsabilidade civil pré-contratual, da ruptura das tratativas e dos critérios de indenização nos casos de descumprimento de acordos preparatórios, em uma abordagem pautada pela atualidade. Não deixa de destacar a posição do homenageado de que se está aqui diante de hipótese de responsabilização no plano pré-contratual, pois, a essa altura, ainda não alcançou o consenso necessário à formação do vínculo contratual propriamente dito. Revela com rigor aimportância prática e aplicação concreta do instituto a partir do exame de relevante julgado do Superior Tribunal de Justiça, no qual se disseca a tormentosa questão (Recurso Especial n ${ }^{\circ} 1.641 .868 / \mathrm{SP}$ ), dentre outros precedentes. E admitindo a dificuldade de quantificar-se o dano nas situações dessa ordem, conclui que o conceito de interesses negativos deve abarcar pretensões vinculadas não somente a danos emergentes, mas também a lucros cessantes, que teriam como limite os interesses positivos do próprio contrato que se viu injustamente frustrado.

A temática desenvolvida por Rogério Donini diz respeito à "Pós-eficácia obrigacional e meio ambiente". Em primeiro lugar, o autor enaltece a necessidade de adotar-se, em uma relação obrigacional, um comportamento efetivamente centrado nas exigências da boa-fé objetiva. Desenvolvea importância de as partes se comportarem com justa correção na fase que antecede ao nascimento o contrato (fase pré-contratual), durante a vigência 
do contrato e mesmo após a sua extinção (fase pós-contratual). Esclarece que se não há no próprio contrato uma disposição específica sobre os efeitos posteriores a seu término (pós-eficácia obrigacional) ou se não há norma legal que preveja tal resultado, deve entrar em cena o tratamento jurídico da responsabilidade civil pós-contratual, com atenção às exigências do que a doutrina convencionou referir como deveres anexos, deveres laterais ou deveres de consideração. $\mathrm{O}$ autor nos convida a aprofundar a reflexão com a seguinte indagação: "se, todavia, em razão de uma convenção surge um dano ambiental depois de sua conclusão, atingindo o outro contratante ou terceiros, seria o caso de pós-eficácia real ou aparente?" Delineando os contornos da proteção à dignidade humana, conclui que o direito ao meio ambiente equilibrado se insere no rol de direitos da personalidade (Direitos de Humanidade), e, como tal, é merecedor de eficiente proteção jurídica.

Em artigo intitulado "As cláusulas de redução e exclusão da reparação de danos e o fenômeno da incidência jurídica", Ragner Limongeli Vianna desenvolve estudo que parte da Teoria Geral do Direito, ramo de profícua investigação do homenageado. Apresentando reflexões sobre a hipótese de incidência na reparação de danos, com apoio nas lições de Orlando Gomes, Fernando Pessoa Jorge e juristas da mais elevada envergadura, o autor examina as causas de redução e exclusão da obrigação de reparação de danos, bem destacando o fenômeno da incidência jurídica. Traz à baila o exame das consequências da não incidência e nos encanta com a importante lição de que os casos genericamente referidos como causas excludentes da obrigação reparatória, são, em parte, situações jurídicas nas quais há "o efeito de impedir o nascimento da relação obrigacional reparatória". Com essa advertência, o autor traz luz para o sempre desafiador e tormentoso nexo causal. O autor revela as potencialidades de aplicação concreta do tema, com julgados que enfrentam a problemática do nexo causal à vista do fenômeno da não incidência da norma jurídica. $\mathrm{E}$ não descura do exame do que se convencionou denominar casos fortuito interno e externo. Em uma visão científica, cuidadosa e primorosa do fenômeno da incidência, o autor enaltece o brilho a que o homenageado faz jus.

"ACulpano Direito das Obrigações: notas para uma história de conceitos jurídicos fundamentais" é a valiosa contribuição de Judith Martins-Costa e Luca Giannotti. Os que conviveram com Renan Lotufo testemunharam seu afeto e admiração acadêmica pela autora, que, nas suas palavras, representava a proeminência feminina nas letras jurídicas do Direito Privado. Em um primoroso e denso ensaio, os autores cativam oleitor apresentando a evolução da culpa desde seus primórdios. Nas linhas e entrelinhas, perfilhando as lições do homenageado, o texto nos seduz ao demonstrar que "a culpa não estámorta". O artigo é referto de ciência e poesia: parte das regras de imputação do dever de indenizar nas origens arcaicas e romanas; debruça-se sobre a culpa do Direito Intermédio ao Jusracionalismo e, no Direito brasileiro, com erudição, traça os contornos dos conceitos de culpa, imputação e causalidade. Não escapa da atenta pena dos cultos autores a relação entre culpa, imputação, causalidade e ilicitude. Cada conceito que desenvolvem desdobra-se em infinitas (e novas) possibilidades de compreensão do fenômeno jurídico. Com sapiência e profundo senso de Justiça, tocam-nos com um estudo que se revela permeado por magia e encantamento. É um ensaio que nutre o leitor ávido por compreender os fenômenos jurídicos. Os autores nos convidam a perquirir o real itinerário da culpa. "Da culpa ao risco?" Ou, ao reverso, indagam, "do risco à culpa?" A densidade das reflexões do ensaio põe em dúvida o "Ocaso da culpa" (como igualmente fez Renan Lotufo). Com fina sensibilidade, os autores nos 
convidam a investigar: "será (o ocaso da culpa) verdade? O ocaso não será tão somente da unicidade dos fatores de imputação de responsabilidade?". Ciência e beleza transbordam em cada linha do texto, fascinando os que cultuam o Direito Privado.

"18 anos de Código Civil e a maioridade do papel da 'culpa' na consolidação do sistema de imputação da responsabilidade fundado no risco. Uma visão a partir de Renan Lotufo". É esse o título do artigo com o qual Diogo Leonardo Machado de Melo contribui a essa merecida homenagem. Interessado em investigar a culpa, o autor nos lembra a lição do homenageado de que os institutos jurídicos não são "abandonados do dia para a noite, e muitas vezes cabe à doutrina atualizá-los à luz das novas necessidades e premissas constitucionais". Traçando os contornos de um modelo (uma "regra matriz de incidência") de aferição da culpa dentro dos novos paradigmas da responsabilidade civil, sublinha a perspectiva de Renan Lotufo, para quem a culpa, renovada, permanece viva. Com apoio na melhor doutrina nacional e estrangeira, contribui com oportuna referência à Teoria Geral do Direito, examinando a regra matriz da incidência das normas, sob inspiração da metodologia civil-constitucional. No seu entender, a despeito da objetivação da responsabilidade civil, não se deve abandonar o modelo de um padrão ético imposto pelo ordenamentojurídico para a vida em sociedade (e à responsabilidade civil que nelabrota). Examina com percuciência o nexo causal (a partir do nexo de imputação), na busca de uma renovada leitura das condutas socialmente relevantes. Com a mesma pertinência, indaga se "a culpa exclusiva da vítima é apenas um problema de causal idade?", com o que incita o leitor ao raciocínio crítico sobre temas basilares da Responsabilidade Civil. Na sua conclusão, Machado de Melo pondera que "(a) apreciação da culpa deverá sim obedecer a um critério flexível, variável, proteiforme, como, aliás, ocorre nos princípios e na formação de standards de comportamento, sendo artificial tratarmos a culpa extracontratual sem consideração a aspectos concretos, desprezando considerações pessoais, temporais, materiais, quantitativas, enfim, valorações afastadas da própria realidade do caso". Diante dessa advertência, o homenageado estaria, com justa aprovação, a sorrir para o autor.

Susete Gomes singra o intrincado tema da "Responsabilidade civil (social) na sociedade complexa". A autora examina com profundidade os contornos da sociedade complexa contemporânea, que é marcada pela pluralidade, pela diversidade de ideias e infinita gama de incertezas, em um fluido ambiente no qual emergem, dia a dia, novos papeis a serem exercidos pela responsabilidade civil. E nessa caleidoscópica e líquida realidade, a autora invoca o homenageado, que jamais cansou de lecionar que a beleza do Direito Civil reside em nascer da sociedade, e nela permanentemente renascer e a renovar-se. "Em tempos que se vive a quarta revolução industrial marcada pela convergência de tecnologias digitais, físicas e biológicas, como atribuir responsabilidade civil de forma individualizada, com discussão acerca da culpabilidade?", indaga-nos a autora, com propriedade. Na sequência, propõe modelos jurídicos para analisar a conveniência da ampliação da responsabilidade civil às fronteiras da responsabilidade social, o que faz com apoio em abalizada doutrina nacional, concluindo, com segurança, pela importância de alinharmo-nos ao que refere como uma responsabilidade civil social na sociedade complexa, com vistas à atividade, passagem em que rememora as palavras do homenageado: "a atividade está sempre presente como condição de manutenção de dignidade do ser humano".

Cláudio José Franzolin desafia a hodierna temática da "Violação de dados pessoais sensíveis e os danos aos direitos de personalidade: responsabilidade civil especial numa 
perspectiva do estudo das cidades inteligentes (smart cities)". O autor destaca a relevância das tecnologias baseadas em inteligência artificial e algoritmos de combinação de dados pessoais, que, usados na gestão urbana, propicia a criação do ambiente que, na contemporaneidade, é referido como as cidades inteligentes. Procura estabelecer a relação entre tais cidades inteligentes e sustentáveis e o acesso, emprego e manipulação de dados da pessoa, que, a um só tempo, fomentam a gestão da política urbana e promovem o ser humano, realizando a efetividade dos seus direitos fundamentais. Não escapa da fina percepção do autor, na sequência, os danos e os riscos que decorrem da captação de dados pessoais, em sua relação com as cidades inteligentes para a realização eficiente do bem estar da pessoa humana, razão final de toda atividade da vida em sociedade, com o enfretamento das normas estrangeiras e nacionais a respeito do tema. A proteção dos dados sensíveis e os contornos da Lei Geral de Proteção de Dados não se esquivam da atenta pena do autor: examinando-os em profundidade nessa temática, identifica que tal contexto pode vir a originar novos danos, com os quais o intérprete deve aparelhar-se para bem lidar em um universo em construção, permeado por datamining e machine learning. Sob o risco de novos danos, adverte o leitor do imperativo de prudência na combinação de dados pessoais, de modo que se possa garantir, permanentemente, o pleno desenvolvimento da personalidade com sustentabilidade.

"Notas sobre a responsabilidade civil no direito de vizinhança" é a contribuição de Silvio de Salvo Venosa e Roberta Densa a essa obra em homenagem a Renan Lotufo. Os autores desenvolvem a relação entre o direito de vizinhança e a responsabilidade civil, partindo do conceito de vizinhança, e traçam os contornos da responsabilidade civil entre vizinhos. Apresentam as consequências de se estar diante de uma relação jurídica fática entre vizinhos, de caráter propter rem, o que fazem, em especial, com arrimo na abalizada doutrina de San Tiago Dantas. Enfrentam os lindes dos atos ilegais, atos abusivos e atos lesivos e não deixam de averiguar os contornos do abuso do direito de vizinhança e de sua importância para a conformação da responsabilidade civil. Preocupam-se, ainda, com os limites de tolerabilidade e com o exercício do direito de uso da propriedade em padrões de razoabilidade. Na sequência, após oportuna reflexão sobre a teoria dos riscos envolvidos na disciplina, desenvolvem hipóteses nas quais responsabilidade civil entre vizinhos pode ser considerada objetiva. Contribuem com importante passo para o estudo do tema em causa, analisando com percuciência as vertentes da teoria do risco (risco integral, risco proveito, risco criado), com o destaque necessário aos elementos de anormalidade e extraordinariedade do risco.

Adriano Ferriani e Carlos Alberto Ferriani discorrem com autoridade nas suas "Reflexões sobre a força maior e o caso fortuito". Os autores apresentam os lineamentos das duas formas de atos ilícitos previstas no Código Civil, como estabelecem os artigos 186 e 187. Destacam, logo de início, a importante lição de que o dano não é requisito para caracterização do ato ilícito na concepção puramente subjetiva, mas o é para o tema da responsabilidade civil, pois à responsabilidade civil importa o ilícito que, ao final, vem efetivamente a danos causar. Sublinham, com pertinência, que o art. 187 do Código Civil não alude à existência de dano à concepção objetiva do ilícito nele disciplinada, no que trazem importante contribuição para o bom entendimento do ato ilícito. Na sequência, debruçam-se sobre os lindes do caso fortuito e força maior, com a justa preocupação de frisar sua operabilidade nos campos das responsabilidades contratual (negocial) e extra- 
contratual. Numa importante reflexão, pinçam e examinam (i) casos em que o Código Civil alude apenas ao caso fortuito (arts. 492, § 1 $1^{\mathrm{a}} ; 575 ; 667, \S 1^{\circ} ; 862$ e 868); (ii) casos em que o Código Civil refere somente à força maior (arts. 607; 625, inc. I e II; 636; 642; $650 ; 696$, § único; 702; 719; 734; 737; 741; 753 e 936) e (iii) casos em que o Código Civil cumulativamente refere a caso fortuito e força maior (arts. 246; 399; 535 e 583), distinção a partir da qual pretendem esquadrinhar os contornos entre tais institutos. Não escapam de sua atenta pena os elementos de impossibilidade, inevitabilidade e superveniência, os quais devem estar presentes para que se que surta efeitos no dever de indenizar. Com apoio em Agostinho Alvim, Mestre de todos nós, concentram seus estudos na necessariedade do fato em função da impossibilidade do cumprimento da prestação. Os autores nos brindam com a final reflexão de que se nota "uma tendência para abolir as expressões caso fortuito e força maior. Tem-se preferido usar a fórmula ausência de culpa". A contribuição dos autores para o desenvolvimento da Ciência do Direito merece aplausos da comunidade jurídica e faz jus ao homenageado.

"Nexo de causalidade e o dano indireto no direito brasileiro" é o aporte de Gustavo Tepedino à merecida homenagem a Renan Lotufo. Partindo do estudo das teorias que enfrentam o nexo de causalidade e o dano indireto, o autor examina com profundidade o perfil do nexo causal na jurisprudência brasileira, missão hercúlea que se revela árida diante de multiplicidade de enfoques dispensados ao tema pelas Cortes de Justiça do Brasil. Esquadrinha com percuciência os contornos da causalidade múltipla e bem desenvolve os seus efeitos na responsabilidade civil. Enfrenta as teorias da equivalência das condições; da causalidade adequada; da causalidade eficiente e da causa direta e imediata (teoria da interrupção do nexo causal), que, sob a vertente da subteoria da necessariedade da causa, tem encontrado prevalência na jurisprudência do Brasil. O autor apresenta e examina com brilho relevantes julgados do Superior Tribunal de Justiça que enfrentam o nexo causal no plano indenitário. E esquadrinha com maestria o dano indireto pelo Supremo Tribunal Federal. Para tanto, invoca e disseca quanto decidido no Recurso Extraordinário $n^{\circ}$ 608.880/MT: enfrenta a delicada responsabilidade civil do Estado por danos morais e materiais em razão de latrocínio praticado por criminoso que, cumprindo pena em regime fechado, evadira do presídio três meses antes do crime. Com essa análise, demonstra ao leitor a prevalência da teoria da necessariedade da causa na Corte Constitucional do Brasil, frisando a "imprescindibilidade do delineamento de parâmetros homogêneos para o seu estabelecimento no sistema jurídico brasileiro".

Teresa Ancona Lopez desenvolve a relevante temática da "Obesidade, nexo causal e responsabilidade". De início, traz ao leitor a lúcida advertência de que "a responsabilidade pelo combate à obesidade não significa responsabilidade pela obesidade". Na sequência, nos apresenta os contornos da relação entre a obesidade e a restrição à publicidade de alimentos e bebidas, tanto em um panorama nacional, quanto no cenário internacional. Põe em destaque, com a percuciência que lhe é própria, a importância das ações civis públicas, e traz à baila as principais questões referentes à responsabilidade civil pela obesidade, assumindo destaque o dever de informar e a relação de causalidade. Na sua lúcida conclusão, põe em evidência o papel da sociedade e do Estado na implementação de políticas públicas de controleà obesidade. Clama pela responsabilidade das empresas e do Estado, com atenção à informação adequada a ser dispensada aos jovens sobre o perfil nutricional dos produtos com vistas a desestimular o consumo excessivo. "O único modo de melhorar 
essa epidemia éatravés de políticas públicas permanentes eagressivas, seja com relação ao próprio obeso, seja para proteger as crianças e mostrar que se há obesidade infantil é por culpa dos pais e não da fábrica de sorvetes ou salgadinhos", conclui a autora, instigando a profícua reflexão de cada um de nós.

Carlos Frederico Barbosa Bentivegna desenvolve a sempre oportuna temática das "Penas privadas e responsabilidade civil". No início, convida-nos a refletir sobre o fenômeno da erosão dos tradicionais filtros da responsabilidade civil, com destaque à passagem da culpa para o risco e ao papel que o nexo de imputação ocupa no dever de indenizar. Na sequência, examina os perfis do nexo causal e do dano, nas suas múltiplas vertentes. Aporta, então, no estudo das funções da responsabilidade civil, ponto em que concentra sua atenção na função punitiva da responsabilidade civil. Nesse contexto, entra em cena a admissibilidade das penas privadas no Brasil, o que também se esquadrinha nos lindes da responsabilidade civil. Procura vencer, com apoio na melhor doutrina, a resistência oposta a tal percepção por doutrinadores de tomo. Pondera que o Código Civil admite penas privadas em diversas passagens, aludindo, a título de exemplificação, aos artigos 555 , $773,939,940$ e 941 , dentre outros. Por fim, ao referir às lições que podem ser colhidas do Direito Penal, acentua ser necessária a "desmistificação" do dogma de separação da função punitiva segregada apenas aos lindes do Direito Penal, o que, nas suas palavras, "em muito contribuirá para a segurança jurídica e para a moralização das situações indenizatórias".

Andrea Cristina Zanetti explora as "Reflexões sobre o dano indireto indenizável e sua expansão na responsabilidade civil extracontratual". Após desenvolver o perfil jurídico do dano indireto (dano reflexo ou dano por ricochete), a autora se vale das lições extraídas do direito anglo-saxão e francês (dommage par ricochet) e pontua as distinções no tratamento da questão no Brasil. Na sequência, analisa sua indenizabilidade, entre nós, diante da dicção do art. 403 do Código Civil, no que se ampara em farta construção doutrinária para contrapor teses a respeito do tema, concluindo pelo seu acolhimento. Mais tarde, com pertinência, põe em destaque o dano indireto indenizável e sua interface com a subteoria da causalidade necessária, bem assim a influência das concausas na identificação do nexo causal. Para tanto, traz à baila elucidativas hipóteses de verificação do problema. Ainda, examina o art. 948 do Código Civil, no que interessa à configuração da situação jurídica do lesado por dano indireto indenizável (sede em que se encontra sua positivação, no entender da autora). Pondera os danos causados a terceiros em virtude de um mesmo evento morte, em graus, hipóteses, fundamentos, legitimados e intensidades distintos, inclusive no que diz respeito aos danos existenciais (danos extrapatrimoniais indiretos concomitantes), no que se apoia em importante construção da jurisprudência brasileira para identificar o dano indireto indenizável.

Giovanni Ettore Nanni integra esta obra coletiva com densa contribuição: "Desconto de proveitos ("compensatio lucri cum damno"). Inicialmente explorando a relação de equivalência que norteia a indenização com a extensão do dano (CC, art. 944), discorre sobre a noção de 'desconto de proveitos' estabelecendo que eventual benefício alcançado pela vítima, originado do mesmo fato que a lesou, deve ser considerado no montante indenizatório para finalidade de decote, sob pena de enriquecimento sem causa (CC, art. 884). Didaticamente o autor, com apoio em sólida doutrina estrangeira, assevera que a designação "compensatio' não se apresenta correta haja vista que o instituto tem por escopo a retirada de projeções vantajosas no momento de se calcular a indenização e não o abatimento por 
outro e qualquer crédito. Declina estruturalmente os requisitos do instituto, dentre eles: a existência do benefício a favor do lesado, a origem comum entre vantagem e lesão e o liame causal em unicidade. Adentrando à seara dos efeitos, indica que a principal repercussão do desconto de proveito se dá na quantificação da indenização, mas pode, se for o caso e a depender do valor envolvido, diminuir significativamente o montante ressarcitório ou mesmo apagar a indenização se as vantagens se estenderem com superioridade à lesão sofrida. Artigo com nítida excelência, a despeito da pouca referência atribuída pela jurisprudência nacional, como adverte o autor.

Maria Helena Diniz e Maria Helena Marques Braceiro Daneluzzi unem-se nessa homenagem a Renan Lotufo com o ensaio intitulado "Responsabilidade Civil por dano à privacidade". As autoras afirmam, de início, a importância da responsabilidade civil na reparação do dano extrapatrimonial, com oportuna advertência de que a determinação dos critérios de quantificação do dano moral pelo julgador é um dos grandes desafios da ciência jurídica. Desenvolvem, ao depois, o perfil da lesão ao direito da personalidade da pessoa natural, protegido pelo art. $5^{\circ}$, incs. X e XI, da Constituição Federal de 1988: trata-se de realidade complexa em um "admirável mundo novo unido pela força da mídia e pela transnacionalização da rede mundial de computadores". Apresentam ao leitor a tutela da privacidade sob os aspectos social, psicológico, comunicativo, territorial, corporal e apropriativo. Com segurança, traçam a linha distintiva entre os conceitos de privacidade e intimidade, por não se dever admitir a confusão entre tais institutos, como, por diversas oportunidades, fez sublinhar o homenageado. Por fim, elencam extenso rol de condutas caracterizadoras a violação da privacidade pelos meios eletrônicos de comunicação. E indagam: "como restringir o campo de atuação dos meios de comunicação em busca de sensacionalismo, desprezando a dignidade da vida privada da pessoa?" Esquadrinham os contornos dos princípios da diferença e da exclusividade das opções pessoais. Não deixam de se preocupar com o (des)respeito ao direito à privacidade da pessoa humana, tema árido na Ciência do Direito enfrentado com plena desenvoltura. Em arremate, propõem critérios de quantificação das ofensas ao direito de propriedade, concluindo, em atual abordagem, que "é preciso respeitar a autodeterminação informativa sobre a vida privada por haver liberdade do titular para moldar o objeto de proteção desse direito, que verificará fatos relevantes de sua privacidade, autorizando, ou não, sua divulgação".

"Por uma tipologia dos danos extrapatrimoniais" é o título da contribuição de Nelson Rosenvald à presente obra. Depois de apresentar as razões pelas quais parte da doutrina entende se justificar a substituição da expressão Responsabilidade Civil por Direito de Danos, o autor traça o itinerárioda afirmação daindenizabilidade dos danosextrapatrimoniais: perpassa pela conformação que lhe impôs o Código Napoleônico, o BGB, até chegar ao estágio atual entre nós, que marca, nas suas próprias palavras, "um significativo avanço civilizatório". O seu textoé recheado por observações extraídas de notas de aulas proferidas pelo homenageado, que tocam profundamente o leitor, trazendo genuína emoção aos que tiveram o privilégio de com ele conviver. O autor envida esforços para conceituar o dano moral, passando de uma inicial figura retórica para, em umestágio de maior evoluçãocientífica, permitir reconhecê-lo como uma reação do ordenamento jurídico à violação de um direito da personalidade. É um conceito ainda em construção, que, ultrapassando seis estágios de evolução, hodiernamente pode ser entendido como "uma lesão a um interesse existencial concretamente merecedor de tutela". Em uma precisa reflexão, o autor busca estabelecer a relação entre o dano moral 
e a tipologia do dano extrapatrimonial. Busca superar a abordagem tradicional (enão necessariamente correta) de que "o dano moral e o dano extrapatrimonial se equivalem". E não deixa de se preocupar, ademais disso, com o dano estético e o dano à imagem, para aportar, por fim, no dano existencial ("o mais recente membro da prole do dano extrapatrimonial"). Sublinha a importância da distinção entre o dano moral e o dano existencial, e conclui pela acolhida da tipologia aberta do dano extrapatrimonial "na tentativa de mapear uma zona inóspita da responsabilidade civil brasileira".

Alexandre Guerra nos recorda os ensinamentos de Renan Lotufo a partir do artigo "Três lições de responsabilidade civil: a coexistência de três modelos de responsabilidade civil. A morte da culpa e a Fênix. A indenização social para entidades de beneficência". A abordagem dogmática é prudente ao estabelecer diferenciações e, ao mesmo tempo, convivência pacífica e coordenação entre os modelos lecionados pelo homenageado. Adverte que a censurabilidade da conduta (culpa), a objetivação da imputação (risco) e a indicação legal de rubricas indenizáveis preestabelecidas a favor das vítimas (tarifação) não são incoerentes entre si, representando a plasticidade assumida ao longo da evolução humana pela responsabilidade civil. Num ponto se giza algo fundamental: não há razão para pretextar a inconstitucionalidade da responsabilidade tarifada se referido arquétipo, mesmo que insuficiente em adimplemento, pode restar complementado pelos demais standards na satisfação dos direitos do lesado. A latere e em competente coerência à abordagem inicial, desenvolve densa análise quanto ao papel renovado da culpa na perspectiva da legalidade constitucional (que o valha as liberdades fundamentais) e os chamados danos sociais, porquanto se a sociedade padece em virtude do rebaixamento causado pela prática do ilícito, é ela mesma, através das instituições de beneficência, que deve ser indenizada e promovida.

Ronnie Herbert Barros Soares apresenta pesquisa sobre a "Responsabilidade civil por perda de uma chance". Na base, inicia o tema na perspectiva de composição da chance, indicando-a na rica metáfora relativa à expectativa do lesado, pois o "futuro do presente se torna futuro do pretérito". Também alinha preliminarmente o cabimento da perda da chance à luz do direito brasileiro, situando-a tanto no paradigmático exemplo do julgado do Superior Tribunal de Justiça frente ao episódio do "Show do Milhão" como nos demais exemplos de danos decorrentes das atividades de profissionais liberais (especialmente médicos e advogados), assim como nas prestações de serviços que interrompem a boa possibilidade de êxito por parte do lesado (impedimento de participação em concurso com atraso em transporte aéreo). Alude, forte em excelentes referências bibliográficas, que a chance não se depura em fórmulas matemáticas, senão pela verificação da inerente seriedade, deixando de lado meras conjecturas ou ilusionismos utópicos. O texto aproveita para advertir sobre sério equívoco havido na dogmática, assim como em alguns julgados: a perda da chance não se confunde com danos morais, já que também pode ter externalidades patrimoniais. Didaticamente contribui com a paráfrase de que enquanto o dano é pressuposto da responsabilidade civil, "a perda chance" também traduz a ideia de dano, contudo sob a necessidade de parametrização, e, via de consequência, a reparação e compensação (como escopos da responsabilidade civil) são condições de harmonização de todos no convívio social.

"Quantificação do dano na perda de uma chance de cura ou sobrevivência" é o título da contribuição de Miguel Kfouri Neto. Na responsabilidade civil médica, fixar a indeni- 
zação pela perda de uma chance de cura (ou de sobrevivência) é uma operação plena de dificuldades, que, como tal, desafia o intérprete. Se, de um lado, é certo que como regra, o profissional da área médica não causa diretamente o prejuízo final (morte ou agravamento do estado clínico), é igualmente certo que há casos em que a sua conduta é capaz de diminuir a probabilidade de cura ou de sobrevida do paciente. A chance perdida, nas lúcidas palavras do autor, "deve ser vista como um prejuízo específico e autônomo, mas não deve ser confundido com o prejuízo final e nem constitui fração deste". Com apoio na melhor doutrina e em compasso com a orientação das Cortes de Justiça do Brasil e do exterior, o autor examina com profundidade algumas etapas a serem observadas na valoração do dano (e na quantificação da indenização) pela perda de uma chance. O seu absoluto domínio na seara da Responsabilidade Civil médica permite fornecer ao leitor excelente referencial teórico para bem esquadrinhar os contornos de uma temática candente, relevante e complexa.

"Fundamentos da Responsabilidade Civil Objetiva Extracontratual" é o título da pesquisa desenvolvida por Marcelo Benacchio. O tema reflete não apenas o vastíssimo campo de atuação da responsabilidade civil, mas essencialmente a intensa adaptabilidade do instituto na recepção das evoluções e irritações da sociedade humana, o que torna a investigação filosófica do direito (juízo a posteriori) e a análise pela teoria geral do direito (juízo a priori) imprescindíveis na formulação de novas hipóteses, consequências e respostas à vida comunitária. O autor enumera cinco critérios indicados como fundamentos da responsabilidade sem imputação por volição, ou seja, a chamada responsabilidade civil objetiva, a saber: risco; perigo; equidade; lei e equilíbrio de patrimônios. Entretanto, permite-se, corretamente, ao juízo crítico dessas formulações, porque: existem riscos tratados subjetivamente (trânsito) e objetividades sem riscos (coisa lançada de prédio); perigos tidos como riscos quando na realidade expressam situações normais; princípio metajurídico aberto que contribui para insegurança do instituto (equidade); disposições que ao invés de fundamento são valorações legislativas à situação concreta. Como enfrentado, o equilíbrio patrimonial entre lesante elesado, desde que balizado pela solidariedade, expressa fundamento mais adequado à responsabilidade objetiva extracontratual.

Melisa Cunha Pimenta enfrentou e desenvolveu com inegável segurança o tema "A Responsabilidade Civil Médica e o Seguro de Responsabilidade Civil”. O texto dividido em três eixos fundamentais avança em explicitar a responsabilidade civil do profissional médico, a figura do seguro de responsabilidade civil e a contratação do seguro da responsabilidade civil na perspectiva da atividade médica. Os pressupostos para a responsabilização do médico são alinhados historicamente (Code Napoleon), assim como na contemporaneidade, seguindo as premissas sistemáticas que subjazem à eventual reparação e compensação pelos danos, dentre elas a necessidade de liame causal, bem como a conduta caracterizada pela culpa, agregando neste campo intensa coordenação entre o Código Civil (art. 186), o Código de Defesa do Consumidor (art. 14, $\S 4^{\circ}$ ) e, deontologicamente, o Código de Ética Médica. Explicita, noutro viés, o seguro da responsabilidade civil como essencial à relação entre médico (eventual lesante) e paciente (possível lesado), notadamente porque garante o pagamento de indenização preservando o status quo ante já que a atividade do profissional, a despeito dos avanços em termos tecnológicos, é melindrosa com destacados deveres de cuidados. Por fim, abordando o contrato de seguro declina especial atenção à boa-fé objetiva, princípio estruturante e funcional, que nas relações securitárias tem essencial proeminência sobre condutas e informações entre segurador e segurado. 
Keila Pacheco Ferreira apresenta e conduz denso artigo intitulado "Princípio da Reparação integral: feição clássica, insuficiências e expansão funcional da responsabilidade civil”. Já na introdução, lastreada em excelentes referências bibliográficas estrangeiras, ressal taa proeminência do princípio da reparação integral enquanto originalmente concebido e perfilhado na intensa relação coordenada entre dano e indenização, invocando, para tanto, as três funções primordiais (compensatória, indenitária e concretizadora). Sustenta que referido princípio tem arrimo em valores fundamentais os quais promovem a pessoa (âmbito existencial) e os respectivos interesses econômicos (âmbito patrimonial). À luz dessas percepções, indica que o princípio da reparação integral enquanto positivamente tende a evitar o enriquecimento sem causa, desliza negativamente em deixar de esboçar estratégia preventiva, tornando obstáculo ao direito restituitório daquele que opera em ilícito lucrativo. E, entrelaçando com essa última perspectiva, inclui no tópico seguinte e não sem razão, críticas também já desenvolvidas por outros autores que respeitam à insuficiência do princípio da reparação, mesmo porque a expansão de novos danos, derivados dos avanços inovadores e disruptivos, exigem a ampliação multifuncional da responsabilidade civil. Um belo texto.

Álvaro Villaça de Azevedo traz à lume o artigo "Responsabilidade civil e socialdo Estado. Minha proposta de subclassificação de responsabilidade civil extracontratual objetiva: em pura eimpura". A rigor, trata-se de renovação de pioneira reflexão teórica festejada pela doutrina e publicada na década de 90 , antes da entrada em vigor do Código Civil atual. Para o autor a responsabilidade objetiva impura tem, sempre, como substrato a culpa de terceiro, que está vinculado à atividade do indenizador. Enquanto, a responsabilidade objetiva pura implica ressarcimento, ainda que inexista culpa de qualquer dos envolvidos no evento danoso. Neste caso, indeniza-se por ato lícito ou por mero fatojurídico, porque a lei assim o determina. Entre as diferenças das subclasses teóricas criadas fixa-se justamente o direito de regresso, presente na modalidade objetiva impura e ausente na objetiva pura. E justamente essa projeção será igualmente adotada na análise da responsabilidade do Estado que tem o dever de zelar pela coletividade, inclusive pelos riscos que ela corre em razão de caso fortuito ou de força maior, como revolução, guerra, pandemia, que podem torná-la vulnerável a sofrer, pela fome, pelo frio ou pela falta de vestimentas e habitação.

No artigo "A responsabilidade extracontratual das pessoas privadas prestadoras de serviço público", Clovis Beznos estabelece paradigmas que demonstram a evolução da responsabilidade do Estado pelos danos causados, até aportar na contemporaneidade. Inicialmente remonta a teoria da irresponsabilidade própria de Estados Absolutistas e caracterizados pelo direito repressivo, aduzindo que eventual exceção poderia decorrer na imputação direta ao servidor público. Evolui no histórico indicando a superação da praxe absenteísta pela teoria civilista da culpa, com nítida clivagem entre atos de império e de gestão, donde apenas no último era possível inquinar a responsabilização estatal, dada a noção de igualdade com os cidadãos. Entretanto, é no famoso caso Agnes Blanco que a responsabilidade do Estado flui mediante novos contornos, ensejando duas diretrizes essenciais: consolidação em França da jurisdição administrativa e a inserção de princípios de ordem pública atinentes à atuação estatal, desprendendo-se das bases civilistas. $\mathrm{O}$ Ârret Blanco mais à frente proporcionou a entrada de novas teorias, com destaque à culpa anônima pelo serviço seguida do risco administrativo. Na conclusão, o autor em sólida argumentação define o fundamento da responsabilização do Estado tanto pela teoria 
do risco administrativo como também no princípio da igualdade (igual distribuição de encargos), sendo que já no âmbito das pessoas jurídicas privadas prestadoras de serviço público o risco administrativo é o único fundamento, projetando ônus exclusivo de arcar com recursos próprios a indenização pelas lesões proporcionadas.

Margarida Araújo Seabra de Moura no artigo "Responsabilidade civil por omissão e a Lei Brasileira de Inclusão" explana com experiência sobre as consequências da inação estatal frente aos direitos recentemente internalizados no Brasil quanto às pessoas com deficiência. Em apertada síntese, o texto indica que a abstenção no cumprimento de deveres expressos, assim como a insuficiência ao prestá-los, na ocorrência de danos, faz surgir a obrigação de indenizar pelo ente estatal. Para tanto realiza análise segura de duas opiniões divergentes, aquela que à omissão se associa a exigência de conduta culposa do Poder Público e outra de que, sendo a matéria estritamente de direito administrativo, não se faz necessária a investigação pela imputação subjetiva, mas ao contrário adapta-se ao risco administrativo. E justamente nesse desiderato declina diversos deveres dos Estados Parte da Convenção Internacional de Direitos das Pessoas com Deficiência notadamente inclinados à promoção desse vulnerável mediante a garantia de direitos humanos e das liberdades fundamentais. No último tópico, em linhade efetividadeà retirada das barreiras não apenas sociais, mas também 'legais', ao desenvolvimento e inclusão das pessoas com deficiência, alia-se à corrente que compreende a dignidade-liberdade como viés interpretativo apto à ressignificação da capacidade civil.

"O dever do Estado de indenizar os contribuintes, pelos danos que abusivamente lhes causar" é o estudo realizado por Roque Antônio Carrazza. O artigo inicialmente faz prudente reflexão sobre a responsabilidade civil nos lindes do direito público e do direito privado, inclusive quanto aos pressupostos. Entretanto, não adota noção "dicotômica das esferas", senão busca a coordenação entre modelos. Neste ponto, revela forte contribuição na passagem de que a responsabilidade civil é verdadeira garantia constitucional com idêntico valor e natureza de outras também previstas no Texto Maior. Discorrendo sobre a responsabilidade objetiva adentra em dois tópicos comuns aos modelos público e privado: o abuso de direito e a teoria risco, o que permite aportar no risco administrativo como espécie consagrada de imputação nas atividades desencadeadas pela Administração Pública. Ao final, sistematicamente alinha ao conteúdo elaborado, após didática separação entre ilícitos típicos e atípicos, a injuridicidade do agir fiscal mediante condutas relacionadas à manifesta exigência indevida de tributos, cobranças de dívidas tributárias já pagas, injustificável cerceamento de defesa e descumprimento do devido processo legal. Enfim, a atividade tributária não pode ser danosa.

Antonio Carlos Morato no artigo "Responsabilidade Civil do Médico pela Perda da Chance" estabelece como premissaà indenizabilidade de danos ocasionadospela atividade médica a verificação do tratamento prestado ao paciente, o que pode ser cotejado à luz da experiência dos demais profissionais, alertando, quanto à cura, que o agente de saúde não se faz vinculado. Tal base vem sustentada habilmente no texto quando da imersão à imputação subjetiva como modo juridicamente adequado para a responsabilização do médico, inclusive no escorço histórico do vetusto e sempre renovado debate quanto à obrigação de meio e de resultado, o que acabou recepcionado pela lei consumerista na adoção da culpa para profissionais liberais. Reflete, com amparo em sólida doutrina e jurisprudência, que a 'perda da chance da cura' provocada pelo erro médico, muito embora 
recepcionada no direito pátrio recentemente, tem sido largamente utilizada porquanto expressa interesse jurídico tutelado, autônomo e revelado na privação da vítima (no caso justamente o paciente) à probabilidade de retomar a qualidade de vida anteriormente abalada. Um renovado salto à responsabilidade civil.

No artigo a "Relação médico-paciente e os elementos da responsabilidade civil" Carlos Alberto Dabus Maluf e Adriana Caldas do Rego Freitas Dabus Maluf conceituam saúde enquanto valor fundamental concernente ao bem-estar psicofísico da pessoa, autorizando o desdobramento de que a relação jurídica havida entre médico e paciente não é tão somente patrimonial, senão existencial, amparada por princípios jurídicos e também disposições deontológicas (como o Código de Ética Médica). Arrimados nesta sólida propedêutica avançam ao explicitar a responsabilidade civil pelos danos ocasionados pelo médico, a partir de premissas relevantes como o dever de informar e igualmente o dever de cuidado, buscando fundamento na clivagem decorrente da obrigação de meio e obrigação de resultado e a imputação decorrente em cada uma dessas hipóteses, não sem antes indicar a culpa como modalidade destinada aos profissionais liberais. Destacam, posteriormente, a responsabilidade civil dos hospitais como sendo objetiva, entretanto com ampla possibilidade de ruptura de nexo causal quanto ao resultado, especialmente em tempos de pandemia.

Excelentes reflexões são apresentadas por Lie Uema do Carmo tomando por base o direito norte-americano no que respeita as questões societárias, emprestando pontos renovados e de ineditismo, o que é mérito, já que expande os limites da responsabilidade civil. Com o tema "Responsabilidade Civil e 'Termination Fee' em M\&A", permite consideração relevante quanto aos chamados "mergers and acquisitions", assim conhecidos os negócios jurídicos ou arranjos empresariais cujo escopo éa alienação de ativos e quotas societárias. Adverte, contudo, que negociações desse naipe representam programas obrigacionais com inúmeros feixes de deveres e que dependem tanto de atendimento às diretrizes externas (autoridades regulatórias, bancos financiadores, fiscalização antitruste), como também à legitimação interna (órgãos de administração e assembleias). Adverte que na práxis nacional os M\&A não contavam com remédios em eventuais casos de impedimento à conclusão da negociação, distribuindo-se o risco entre os atores contratuais. Contudo, aos poucos houve também adesão aos "termination fees" que conduzem à responsabilização da sociedade-alvo no caso de incumprimento da oferta ao proponente ou mesmo na hipótese de inadimplemento pelos termos contratuais. Revela, todavia, contribuição incomensurável quando o artigo debruça-se sobre o conceito e funções da cláusula penal, aproximando-a da figura estrangeira das "termination fees" quer na função indenizatória, quer na função coercitiva de cumprimento.

Arruda Alvim, Eduardo Arruda Alvime Ígor Martins da Cunha enfrentam o tormentoso tema "A responsabilidade civil no transporte aéreo internacional de passageiros: um brevíssimo panorama legislativo e jurisprudencial". O artigo esboça rica notícia histórica enumerando a evolução da legislação interna quanto à responsabilidade civil em torno do transporte aéreo. Colocam em destaque os elementos estruturantes desta responsabilidade civil setorizada, com especial atenção ao ilicito aéreo (inclusive com formação de culpa), eventuais excludentes, limitações nos casos de indenização, tudo isso levando em consideração a extensão espacial do transporte (doméstico ou internacional) e ao bem jurídico lesado (pessoa ou bagagem). $\mathrm{O}$ artigo avança minudentemente nas abordagens 
respeitantes à indenizabilidade quanto aos danos havidos em transporte aéreo internacional de passageiros. Para tanto descrevem intensa movimentação da jurisprudência da Corte Especial (STJ) e Corte Extraordinária (STF) na aplicação do Código de Defesa do Consumidor que, por ser norma de ordem pública e interesse social (cogente e indisponível), não aceita qualquer limitação indenizatória. Encerram discorrendo sobre a atual orientação do direito jurisprudencial.

Marco Fábio Morsello em denso texto proporciona necessária compreensão sobre práticas abusivas de transportadoras aéreas que atuam contra direitos dos usuários. Com o título "Do overbooking ao overselling. Considerações críticas à luz da perspectiva evolutiva da responsabilidade civil do transportador aéreo" o autor enfrenta pontos timidamente tratados na legislação interna como na legislação comunitária. Explicita que o 'overbooking' é a aceitação pelo transportador de reservas para determinado voo em quantidade superior à capacidade da aeronave, o que enseja atraso no voo ou transporte. Ressalta que as fornecedoras de serviços utilizam como argumentação a eventualidade de não apresentação do passageiro e ao, mesmo tempo, a proteção econômica da empresa. Entretanto, o texto não fica neste quadrante. Vai além e apresenta a perspectiva de que atualmente as companhias se valem "overselling" que representa o excesso de venda de bilhetes aéreos, superior à capacidade da aeronave (sobrevenda), o que contratualmente caracteriza ulterior agravante. E neste ponto conclui que a última espécie representa na realidade inadimplemento absoluto da empresa aérea e infração contratual conforme a cláusula geral de da boa-fé objetiva.

Tércio Sampaio Ferraz Junior elaborou um alentado estudo sobre a responsabilidade civil no contrato de transporte intitulado "Transporte de carga, agenciamento de carga e responsabilidade contratual", no qual destacou o sistema logístico inerente ao transporte de carga a entrelaçar meios principais e acessórios a fim de viabilizar sua entrega. Efetuou ainda a distinção entre o transportador contratual e o agente de cargas (enfatizando que esteé responsável por contratar o transporte da mercadoria em nome do cliente exportador/ importador, mas não pela prestação do serviço de transporte) bem como acentuou a relevância da limitação da responsabilidade contratual prevista no artigo 750 do Código Civil.

"Infidelidade, Responsabilidade Civile Teoria do Terceiro Cúmplice" foi o texto apresentado por Carlos Alberto Garbi que, com lastro na teoria do terceiro cúmplice, analisou os efeitos do casamento perante terceiros ressaltando que tal instituto jurídico deve ser respeitado por todos e não somente pelos cônjuges, pois quem interfere nocivamente no matrimônio pode ser responsabilizado se tiver ciência da existência do vínculo conjugal e praticar ato com o cônjuge infiel que ocasione o dano ao cônjuge inocente.

Sob outro enfoque, o tema dos deveres conjugais foi abordado por Débora Brandão em "Repensando a responsabilidade civil pelo descumprimento dos deveres recíprocos entre cônjuges ensejadores da dissolução da relação conjugal" no qual, por meio do exame de duas hipóteses, observou que quando terminam as relações conjugais pode haver tanto a violação dos deveres conjugais previstos no artigo 1.566 do Código Civil a impossibilitar a comunhão de vidas ou, de forma residual, estar relacionada aos danos decorrentes do ato ilícito em sentido amplo. Assim, centrou sua análise na primeira hipótese destacando a resistência doutrinária contemporânea a admitir a possibilidade da alegação da culpa na dissolução da sociedade conjugal e alertou, diante das afirmações de insuficiência do ato culposo de descumprimento do dever conjugal que "parece que se deseja a demonstração 
do cenário desértico a que foi reduzido o outro cônjuge, terra inóspita onde até a presença dos filhos não frutifica sua alma destruída" e, ainda que concorde que há direito de não mais prosseguir no relacionamento, há igualmente a responsabilidade pela conduta adotada no momento da ruptura se esta ocorrer e compara o relevo da tutela da confiança nas relações contratuais em contraste com as relações familiares, nas quais valores relevantes (confiança, boa-fé, verdade, honestidade) pouco ou nada tem valido, o que é inadmissível em sua avaliação.

Luiz Edson Fachin e Roberta Zumblick Martins da Silva prestam uma sensível homenagem a Renan Lotufo por meio do artigo "Inteligência artificial, direito e perquirições: subsídios para um debate em homenagem a Renan Lotufo", sendo oportuno enfatizar que os avanços tecnológicos e temas pouco explorados em Direito Civil sempre inquietaram o saudoso professor em suas aulas, palestras, textos e na orientação de dissertações e teses. Analisa-se, em tal contexto, o projeto Victor desenvolvido em parceria entrea Universidade de Brasília (UNB) e o Supremo Tribunal Federal (STF), uma vez que o autor Luiz Edson Fachin, como Ministro, acompanha sua implementação e desenvolve reflexões oportunas hauridas em sua experiência acadêmica como professor de Direito Civil, apresentando preocupações - ao lado de Roberta Zumblick Martins da Silva como pesquisadora do projeto Victor - com a promoção da inclusão digital e a capacitação de pessoas em situação de vulnerabilidade a fim de evitar vieses discriminatórios, problemas de consentimento e assegurar a proteção de dados.

Claudio Luiz Bueno de Godoy enfrentou um tema polêmico no artigo "Responsabilidade Civil dos meios de comunicação: o controle preventivo e a censura", uma vez que não são poucos os que defendem a exclusão completa de responsabilização dos meios de comunicação e olvidam do equilíbrio exigido pelo texto constitucional que consagra igualmente a proteção da honra, da imagem e da privacidade. Considerando que há igual hierarquia entre os direitos da personalidade e que o texto constitucional é um complexo de normas que apresentam coerência e idêntico grau hierárquico destacou o princípio da unidade hierárquico-normativa. Da mesma forma repudiou o argumento de que há censura quando há proteção aos outros direitos da personalidade expressos na Constituição da República e que vedá-la no texto constitucional não constitui sinônimo de ausência de qualquer limite à circulação das informações quando estas violarem direitos e que o prévio controle judicial não é censura, uma vez que haverá juízo de ponderação a fim de determinar qual direito deve prevalecer no caso concreto.

"O 'tort' anglo-saxão e norte-americano" foi o tema escolhido por Erik Frederico Gramstrup em que reconheceu a dificuldade de obter uma definição unitária de "tort" pela inexistência de um ponto de partida seguro, uma vez que baseados em diversos casos reconhecendo que o sistema da 'Common Law' é avesso a conceitos e classificações abrangentes. Para obter uma definição, analisou os conceitos de "intention", "negligence" e "strict liability" considerando que o "tort" é uma conduta em desacordo com aquela esperada (afastando o sentido meramente moral) e de natureza civil ao qual corresponde uma tutela ("remedy") sem esquecer que há "torts" que derivam da violação da conduta imposta pelo texto legal. Apontou como danos mais frequentes os relativos a direitos reais imobiliários ("interestsin land"), à propriedade de outra natureza, à integridade física, à honra objetiva e ainda a dor psíquica ("mental distress"). Destacou a relevância da Convenção Europeia de Direitos Humanos para o Reino Unido, pois este - na época - foi o primeiro membro a 
ratificá-la. Conclui discorrendo acerca dos principais "torts" no Direito norte-americano e observando que, ao comparar o tema na "Common Law" e nos ordenamentos que são filiados ao "Civil Law" há neste um conceito geral de ato ilícito nos textos legais, mas os tribunais igualmente são importantes porque contribuem de forma significativa para a evolução do estudo da responsabilidade civil.

Paulo Nalin e João Pedro Kostin F. de Natividade elaboraram um estudo sobre "O lucro da intervenção e a tutela de remoção dos ganhos ilícitos" esclarecendo que há lucro da intervenção quando terceiros explorarem de maneira ilícita bens ou direitos com o escopo de obter vantagem e, para tanto, menciona julgado do Superior Tribunal de Justiça (RESp 1.698.701) que considerou o lucro da intervenção como espécie de enriquecimento sem causa assim como desenvolvem interessante análise do "lucro da intervenção" no Direito Alemão e no Direito Inglês para bem interpretar a cláusula geral de enriquecimento sem causa (artigo 884 do Código Civil) no Direito Brasileiro, pois há a justificativa de que responsabilidade civil não possibilitaria qualquer pretensão além da compensação e, por tal razão, há inclinação pelo enriquecimento sem causa para sua fundamentação. Assim, concluem os autores queo "lucro daintervenção" no âmbito da responsabilidade civil deve ocorrer por meio da tutela de remoção do ilícito, mas igualmente que há tutela subsidiária no interno do enriquecimento sem causa.

A "Unificação da responsabilidade civil e seus perfis contemporâneos" foi o artigo elaborado por Carlos Edison do Rêgo Monteiro Filho, no qual, fundado nas lições de San Tiago Dantas e Santos Júnior, discorreu sobre a responsabilidade negocial e a aquiliana, para identificar certa unidade entre tais espécies, mesmo que, eventualmente, haja tratamento diverso destinado a cada uma. Para tanto, ressaltou que a aproximação entre a responsabilidade fundada na vontade ou na lei está centrada em momento interpretativo-aplicativo exemplificado por meio da trajetória da reparabilidade dos chamados danos morais contratuais, pois danos extrapatrimoniais não distinguem a responsabilidade contratual da extracontratual por força do princípio da reparação integral previsto constitucionalmente e que é aplicável tanto a danos extrapatrimoniais como patrimoniais. Asseverou ainda que inexiste razão funcional que justifique distinção quanto ao prazo prescricional, o que fundamenta uma vez mais a unidade, demonstrando que a distinção fundada somente em critérios estruturais sem uma justificativa funcional satisfatória afronta princípios e valores constitucionais.

Maria Cristina De Cicco desenvolveu profícua análise em seu artigo intitulado "O direito ao esquecimentona experiência italiana" em que identificou três gerações do direito ao esquecimento esclarecendo que há bens jurídicos distintos que devem ser tutelados e sua análise deve considerar o direito à memória e à verdade e de forma alguma eliminar o passado ou proteger a impunidade. O direito ao esquecimento, em sua concepção, seria um direito instrumental à concretização de direitos da personalidade e não um direito autônomo da personalidade.

Paulo Mota Pinto escreveu "Sobre a sistematização dos direitos especiais de personalidade", no qual empreendeu relevante estudo acerca das classificações e sistematizações dos direitos especiais da personalidade que devem corresponder, em seu enfoque, a zonas ou dimensões da personalidade consolidadas como bens autônomos que se tornaram objeto de direitos "especiais" em relação ao direito geral de personalidade. Identificou três grandes eixos que podem ser agrupados (integridade, liberdade e identidade) sem olvidar 
dos "direitos de personalidade de autor", pois a obra por ele criada é expressão de sua personalidade. Quanto à teorização do conteúdo do direito geral de personalidade destacou a contribuição de Claus-Wilhelm Canaris quando o incluiu na noção de "autodeterminação informacional" distinguindo a proteção contra a in trusão no domínio pessoal da efetuada perante a difusão de manifestações da personalidade e fatos verdadeiros a fim de destacar a relevância e a possibilidade de aplicação das lições de tal autor em Portugal.

"Responsabilidade Pressuposta" foi o texto elaborado por Giselda Maria Fernandes Novaes Hironaka em que, com precisão, apresentou texto sobre a imputação objetiva de um dano quando a atividade desenvolvida pelo lesante for uma atividade de risco, informado que tal tese foi desenvolvida com base no mise en danger de Geneviève Schamps, sendo que seu escopo é o de favorecer o direito da vítima fortalecendo sua posição jurídica diante de quem lesou sua esfera de direitos e demonstrar a expansão da responsabilidade civil em razão de novos sociais que gerem danos e não estejam em harmonia com fundamentos já conhecidos. Nessa ordem de ideias explicou que o artigo 927, parágrafo único, do Código Civil de 2002 foi inspirado em normas estrangeiras, em especial o artigo 2.050 do Código Civil italiano que permitiu não somente a inversão do ônus da prova, mas um padrão de comportamento mais rigoroso do que aquele esperado do homem médio, uma vez que exigiu a comprovação de medidas apropriadas para impedir que o dano ocorra. Todavia, frisou que o legislador foi além no Brasil porque estabeleceu um fator objetivo de imputação baseado na ocorrência de um dano previsto em lei ou na atividade considerada como perigosa ainda que alerte que o texto aberto da norma demande que certos paradigmas sejam estabelecidos a fim de que existam padrões de fundamentação para viabilizar sua aplicação sem que sejam desconsideradas a segurança jurídica, a previsibilidade e a isonomia.

Encerramos a apresentação desta obra destacando que, neste livro, estão reunidos quatro elementos indispensáveis: o protagonismo; a ciência; a instituição; e os resultados.

O protagonismo presente na pessoa do Professor Renan Lotufo, absoluta referência do direito civil. Desembargador do TJ/SP, advogado e Professor do Programa de Pós-graduação da PUC-SP. Várias das amizades que unem civilistas de todos os cantos do Brasil começaram em suas aulas. Aliás, um grande mestre não se forja apenas em classe ou em palestras: é aquela pessoa que incita o aluno a ir além, apresentando pensamentos divergentes e comparando sistemas jurídicos. Como orientador, fazendo-se presente, conduzindo-nos à reflexão e ao aprimoramento técnico. Nos ensinava que odireito nunca foi unanimidade e que sempre cabia um ou mais pontos de reflexão sobre determinada conclusão jurídica, o que deveria fazer do cientista e cultor do direito alguém humilde e humano, capaz sempre de reconhecer a constante necessidade de evolução do conhecimento.

A ciência representada pela epistemologia da responsabilidade civil. O imenso volume desta obra abordou diversos conteúdos - mas não todos - respeitantes às fontes, aos pressupostos, aos sistemas, aos modelos, à interpretação, aos escopos, às diferenciações da responsabilidade civil, enquanto 'fragmento' incrivelmente vasto na dogmática do direito civil e demais matérias adjacentes. O crédito de pós-graduação conduzido pelo Professor Renan Lotufo na PUC-SP atinente à matéria de obrigações e responsabilidade civil foi observado ao máximo (especialmente em casos difíceis), a fim de que os escritos representassem e revelassem a profundidade e densidade das temáticas desenvolvidas e absorvidas em sala de aula, assim como revelados em seus votos enquanto magistrado de inigualável envergadura. 
A instituição presente na figura do IBERC. O expansionismo dos meios de modos de conhecimento ao longo dosúltimos anos tem proporcionado maior número de profissionais do Direito com titulações em pós-graduações, o queaté os anos noventa do século passado ainda era tímido e mitigado em nosso país. A chegada da sociedade da comunicação não apenas facilitou o acesso à informação (e essa, quando rigorosamente filtrada, ao conhecimento cientifico) assim como a conexão de inúmeros interessados nos avanços e divulgação das pesquisas jurídicas. OIBERC, entre tantas finalidades estatutárias, resume justamente essa atribuição, já que permite o aprofundamento à disciplina da responsabilidade civil, ultrapassando os muros universitários e proporcionando necessárias oportunidades que as entidades educacionais não conseguem prover. O IBERC, pela diretoria e por todos seus associados, sente-se honrado em promover esta homenagem ao Professor Renan Lotufo, até porque o germe desta união institucional foi semeado a partir de suas aulas.

O resultado verificado a partir da quantidade de acadêmicos que com ele compartilharam os valores do ensino, da pesquisa e, sobretudo, da vida. Isso equivale dizer que a generosidade do Prof. Renan Lotufo era demonstrada simultaneamente ao seu rigor acadêmico, uma vez que sempre estimulou cada aluno a alçar voos mais altos e demonstrou, por meio de seu exemplo, que os avanços nas áreas jurídicas seriam sempre paulatinos. Tais lições, como sempre defendeu, não deveriam ser limitadas aos estudantes privilegiados que a recebiam em suas disputadas aulas, mas difundidas em obras e colocadas à disposição daqueles que infelizmente não tiveram a grata oportunidade de conhecê-lo. Ao invés de se isolar e desfrutar do êxito obtido por meio de atividade acadêmica e profissional incansável, preferiu dividir espaços próprios com colegas de docência, da magistratura ou da advocacia e, principalmente, com seus ex-alunos que sempre o veneraram como alguém dotado de desprendimento.

Enfatizamos que tanto os seus orientandos como os alunos das disciplinas que ministrou são gratos à generosidade que demonstrou ao dividir a imensa biblioteca de seu escritório e, com isso, viabilizar relevantes pesquisas ao franquear o acesso a referências bibliográficas que, de outra forma, seriam inacessíveis.

Não à toa que boa parte dos textos reunidos foram marcados pela máxima sempre difundida: "o verdadeiro professor deve ser uma rampa de lançamento dos seus alunos para os seus próprios voos, e não um ponto de chegada. Ele não deve ser um fim; deve ser o começo de uma linda caminhada".

Os leitores serão privilegiados com excelentes textos marcadamente caracterizados pela regência do Professor Renan Lotufo, ficando desde já consignadas nossa gratidão, reconhecimento e condolências à sua esposa, filhos, familiares e inúmeros amigos. 